\title{
Eksplorasi Bakteri Penambat Nitrogen dari Tanah Hutan Mangrove Sungai Peniti, Kabupaten Mempawah
}

\author{
Kabul Santoso ${ }^{1}$, Rahmawati ${ }^{1}$ Rafdinal $^{1}$ \\ Program Studi Biologi, Fakultas MIPA, Universitas Tanjungpura, Jl. Prof. Dr. H. Hadari Nawawi Pontianak, \\ Email korespondensi: kabulsantoso.1503ks@gmail.com
}

\begin{abstract}
Peniti Mangrove Forest is one of the forests in West Kalimantan that has high forest productivity, thus supporting the presence of nitrogen-fixing bacteria. Nitrogen fixing bacteria is one of the nitrogen-fixing microorganisms that can bind the free nitrogen needed for the nitrogen cycle process. This study aimed to determine the types of nitrogen-fixing bacteria that can be found in the soil of Peniti mangrove forest, Mempawah Regency, West Kalimantan. Taking soil samples used a purposive sampling method. Bacterial isolation used dilution techniques and pour plate method on the Nitrogen Free Bromthymol Blue (NFB) media. The nitrogen fixing was obtained by 3 isolates of nitrogen fixing bacteria. After identification, 3 genera were obtained, namely members of the genera Azotobacter, Azospirillum, and Pseudomonas.
\end{abstract}

Keywords: Nitrogen-fixing bacteria, non symbiotic, Peniti Mangrove Forests

\section{PENDAHULUAN}

Hutan mangrove merupakan kelompok jenis tumbuhan yang tumbuh di sepanjang garis lautan tropis maupun sub-tropis, perairannya mengandung garam dan memiliki lahan berupa pantai (Santono, 2000). Hutan mangrove memiliki komunitas vegetasi pantai tropis yang didominasi oleh spesies pohon mangrove seperti tumbuhan bakau, api-api, dan lainnya sehingga bermanfaat bagi biota laut yang tumbuh dan berkembang pada daerah pasang surut pantai berlumpur (Gunarto, 2004). Hutan mangrove juga memiliki peranan yang sangat penting yaitu untuk menjaga stabilitas pantai dari abrasi, sumber ikan, udang dan keanekaragaman hayati lainnya (Setyawan \& Winarno, 2006).

Ekosistem hutan mangrove tidak terlepas dari mikroba yang membantu proses siklus biokimia tanah. Aktifitas mikroba diperlukan untuk menjaga ketersediaan unsur hara makro tanah yang penting bagi tumbuhan, salah satunya yaitu nitrogen. Nitrogen dalam bentuk $\mathrm{N}_{2}$ bebas di atmosfer tidak dapat langsung diserap oleh tumbuhan tingkat tinggi. Tumbuhan menyerap unsur nitrogen dari lingkungannya dalam bentuk senyawa amonium $\left(\mathrm{NH}_{4}{ }^{+}\right)$. Unsur ini dapat diperoleh dari tanah dengan bantuan mikrorganisme yaitu bakteri penambat nitrogen. Senyawa nitrogen organik yang berasal dari dalam sel seperti protein dan asam nukleat akan dilepaskan ke lingkungan dan selanjutnya bakteri yang telah mati dapat dimanfaatkan oleh organisme lain sepertitumbuhan setelah melalui proses mineralisasi (James \& Olivares, 1997)
Penelitian tentang bakteri penambat nitrogen telah banyak dilakukan dan diterapkan dalam berbagai bidang, di antaranya bidang pertanian, lingkungan, dan industri. Bakteri yang hidup bebas pada perakaran dan dalam jaringan tanaman, seperti anggota genera Pseudomonas, Enterobacteria, Bacillus, Azotobacter, Azospirillum, dan Herbaspirillum telah terbukti mampu melakukan fiksasi nitrogen (James \& Olivares, 1997).

Metasari (2012) telah melakukan penelitian eksplorasi bakteri penambat nitrogen non simbiosis pada kawasan hutan mangrove Wonorejo dengan menemukan empat genera isolat bakteri yaitu anggota genera Azotobacter, Azospirillum, Pseudomonas, dan Streptomycetes, Selain itu hasil penelitian lainnya yang telah dilakukan oleh Hartono dan Jumadi (2014), yaitu seleksi dan karakterisasi bakteri penambat nitrogen non simbiotik pengekskresi amonium pada tanah pertanaman jagung dan padi Kabupaten Barru, Sulawesi Selatan, berhasil memperoleh 20 isolat bakteri penambat nitrogen. Kaburuan et al. (2014) juga telah melakukan penelitian tentang isolasi dan karakterisasi bakteri penambat nitrogen nonsimbiotik tanah gambut ada Cagar Biosfer Giam Sak Kecil Bukit Batu dengan memperoleh 31 isolat bakteri penambat nitrogen non-simbiotik dan hasil identifikasi diperoleh tiga genus yaitu anggota genus Azotobacter, Azospirillium, dan Clostridium pasteurianum. Belum ada informasi penelitian tentang bakteri penambat nitrogen dari tanah mangrove Peniti, Kabupaten Mempawah. Berdasarkan ulasan tersebut, maka perlu dilakukan 
penelitian tentang eksplorasi bakteri penambat nitrogen di tanah kawasan hutan mangrove sungai Peniti, Kalimantan Barat.

\section{BAHAN DAN METODE}

\section{Waktu dan Tempat Penelitian}

Penelitian ini dilakukan pada bulan September sampai dengan bulan November 2017. Pengambilan sampel tanah dilakukan di kawasan hutan mangrove sungai Peniti, Kabupaten Mempawah, Kalimantan Barat. Analisis kandungan tanah dilakukan di Laboratorium Kimia dan Kesuburan Tanah, Fakultas Pertanian, Universitas Tanjungpura. Isolasi dan identifikasi bakteri dilakukan di Laboratorium Mikrobiologi, Fakultas Matematika dan Ilmu Pengetahuan Alam, Universitas Tanjungpura, Pontianak.

\section{Keadaan Umum Lokasi Penelitian}

Hutan mangrove Peniti merupakan kawasan hutan mangrove yang berada di sekitar Muara Sungai Peniti, Desa Peniti Besar, Kecamatan Segedong, Kabupaten Mempawah. Hutan mangrove peniti terletak di sebelah utara Kota Pontianak. Secara geografis sungai peniti terletak antara 00011'05" LU dan 109008'14" BT dan antara 00006'13" LU dan 109009'49" BT dengan luas hutan mangrove \pm 390,625 ha. Lokasi penelitian berada di sekitar muara sungai peniti berjarak $\pm 2,7 \mathrm{~km}$ dari jalan menuju kabupaten dan $\pm 43 \mathrm{~km}$ dari Kota Pontianak (Gambar 1).

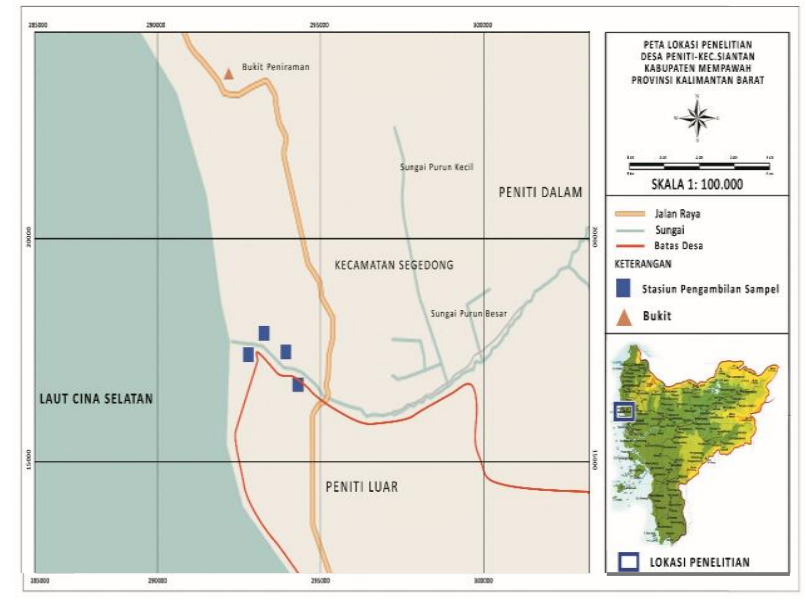

Gambar 1. Lokasi Penelitian

\section{Bahan}

Bahan yang digunakan dalam penelitian yaitu sampel tanah mangrove, akuades, alkohol $70 \%$ dan $96 \%$, larutan iodium, larutan kristal violet, larutan $\mathrm{KOH} 40 \%$, larutan safranin $1 \%$, media Nitrogen Free Bromthymol (NFB) dengan komposisi $\left(\mathrm{K}_{2} \mathrm{HPO}_{4} .3 \mathrm{H}_{2}, \mathrm{KH}_{2} \mathrm{PO}_{4}, \mathrm{MgCl}_{2} .6 \mathrm{H}_{2} \mathrm{O}, \mathrm{NaHCO}_{3}\right.$, $\mathrm{FeCl}_{3} .6 \mathrm{H}_{2} \mathrm{O}, \mathrm{CaCl}_{2} .2 \mathrm{H}_{2} \mathrm{O}, \mathrm{NH}_{4} \mathrm{Cl}$, EDTA, glukosa dan bakto agar) dan uji biokimia yaitu media
Christensen (urea agar base), gelatin, Motility Indole Orhnithin (MIO), MR-VP (methyl red dan voges proskauer), Nitrogen Free Bromthymol (NFB), Simmons Citrate Agar (SCA), dan Triple Sugar Iron Agar (TSIA).

\section{Metode Penelitian}

Penentuan stasiun pengambilan pada penelitian ini menggunakan metode purposive sampling berdasarkan rona lingkungan di kawasan hutan mangrove Peniti. Pengambilan sampel tanah menggunakan metode composite sampling dengan total 20 titik pengambilan dari 4 lokasi berbeda. Parameter faktor lingkungan yang diukur adalah faktor fisikawi dan kimiawi. Pengukuran faktor fisikawi tanah hutan mangrove meliputi suhu udara, kelembapan udara, suhu tanah, kelembapan tanah dan intensitas cahaya matahari. Pengukuran faktor kimiawi tanah mangrove meliputi derajat keasaman $(\mathrm{pH})$, kapasitas tukar kation (KTK), kandungan karbon $(\mathrm{C})$, fosfor $(\mathrm{P})$, nitrogen $(\mathrm{N})$ dan rasio $\mathrm{C} / \mathrm{N}$.

\section{Isolasi Bakteri Penambat Nitrogen}

Isolasi bakteri tanah dilakukan dengan melakukan pengenceran bertingkat dan menggunakan metode tuang (Pour Plate). Langkah pertama yaitu membuat suspensi tanah sampel tanah (komposit) dari lokasi A,B,C dan D dengan cara mengambil tanah sebanyak $10 \mathrm{~g}$ dan dimasukkan ke dalam aquades steril sebanyak $90 \mathrm{ml}$, lalu dihomogenkan menggunakan shaker, Selanjutnya, dilakukan teknik dilusi (pengenceran) pada suspensi tanah dari tiap stasiun mulai dari faktor pengenceran $10^{-1}$ sampai $10^{-5}$ dengan cara diambil $1 \mathrm{ml}$ suspensi sampel, lalu di pipet dan dimasukkan ke dalam tabung reaksi berisi $9 \mathrm{ml}$ akuades $\left(10^{-1}\right)$. Kemudian suspensi dari faktor pengenceran $10^{-1}$ dipipet $1 \mathrm{ml}$ dan dimasukkan ke dalam tabung reaksi berisi $9 \mathrm{ml}$ akuades $\left(10^{-2}\right)$, perlakuan yang sama dilakukan terhadap faktor pengenceran $10^{-3}$. Selanjutnya diambil $1 \mathrm{ml}$ dari masing-masing faktor pengenceran $10^{-1}, 10^{-2}$ dan $10^{-3}$ untuk diinokulasikan ke dalam medium NFB sebanyak 20 $\mathrm{ml}$ pada cawan petri menggunakan metode agar tuang (pour plate) dan diinkubasi selama 72 jam pada suhu $30^{\circ} \mathrm{C}$ hingga didapatkan koloni yang tumbuh (Waluyo, 2008)

\section{Uji Penambat Nitrogen}

Uji ini bertujuan untuk mengetahui bakteri yang dapat melakukan penambatan nitrogen, Isolat murni diinokulasikan pada media NFB semi solid dengan komposisi $\left(\mathrm{K}_{2} \mathrm{HPO}_{4} .3 \mathrm{H}_{2}, \mathrm{KH}_{2} \mathrm{PO}_{4}, \mathrm{MgCl}_{2} .6 \mathrm{H}_{2} \mathrm{O}\right.$, $\mathrm{NaHCO}_{3}, \quad \mathrm{FeCl}_{3} .6 \mathrm{H}_{2} \mathrm{O}, \quad \mathrm{CaCl}_{2} .2 \mathrm{H}_{2} \mathrm{O}, \quad \mathrm{NH}_{4} \mathrm{Cl}$, EDTA, Larutan Bromthymol Blue, glukosa dan bakto agar) yang telah disterilisasi menggunakan autoklaf setelah itu didinginkan, selanjutnya 
ditambahkan 1 ose dari tabung lalu digojok secara perlahan, kemudian diinkubasikan dalam suhu ruang yaitu $30^{\circ} \mathrm{C}$ selama 7 hari. Reaksi positif ditandai dengan terjadinya perubahan warna dari warna kuning kehijauan menjadi warna kebiruan pada media NFB semi solid (Susilowati et al., 2007).

\section{Karakterisasi dan Identifikasi Bakteri Penambat Nitrogen}

Isolat terpilih berdasarkan koloni bakteri yang berbeda dikarakterisasi dan diidentifikasi. Karakterisasi bakteri penambat nitrogen dilakukan dengan menggunakan uji pewarnaan gram, uji Uji urease Christensen (urea agar base), uji gelatin, uji Motility Indole Orhnithin (MIO), uji MR-VP (methyl red dan voges proskauer), uji Nitrogen Free Bromthymol (NFB) semi solid, uji Simmons Citrate Agar (SCA), dan uji Triple Sugar Iron Agar (TSIA)..Proses identifikasi dilakukan dengan mencocokkan karakteristik bakteri penambat nitrogen berdasarkan hasil karakterisasi yang didapat dengan buku identifikasi dan jurnal-jurnal ilmiah yang mendukung. Buku identifikasi yang digunakan diantaranya Cowan and Steel's Manual for the Identification of Medical Bacteria (Cowan et al., 1993) dan Bergey's Manual of Determinative Bacteriology edisi 9 (Holt et al., 1994).

\section{Hasil dan Pembahasan}

\section{Hasil}

\section{Karakterisasi dan Identifikasi Isolat Bakteri Penambat Nitrogen}

Berdasarkan hasil identifikasi didapat 3 anggota genera bakteri penambat nitrogen, yaitu anggota genus Azotobacter (1KSA), Azospirillum (2KSA), dan Pseudomonas (3KSA). Karakteristik makromorfologis koloni tertera pada Tabel 1 dan karakteristik mikromorfologis sel (Gambar 1) tertera pada Tabel 2. Hasil uji biokimia, uji penambat nitrogen (Gambar 2) dan identifikasi isolat bakteri penambat nitrogen dari sampel tanah hutan mangrove sungai Peniti tertera pada Tabel 3.

Tabel 1. Karakteristik Makromorfologis Koloni Bakteri Penambat Nitrogen

\begin{tabular}{|c|c|c|c|c|}
\hline Genus & Bentuk & Tepian & Elevasi & Warna \\
\hline Azotobacter & Bulat & $\begin{array}{c}\text { Tidak } \\
\text { Rata }\end{array}$ & Konveks & Kuning \\
\hline Azospirillum & Bulat & $\begin{array}{l}\text { Rata } \\
\text { Tidak }\end{array}$ & Konveks & Kuning \\
\hline Pseudomonas & Bulat & Rata & Konveks & $\begin{array}{l}\text { Putih } \\
\text { Bening }\end{array}$ \\
\hline
\end{tabular}

Tabel 2. Karakteristik Mikromorfologis Sel Bakteri Penambat Nitrogen

\begin{tabular}{cccc}
\hline Genus & Gram & Sel & Panjang \\
\hline Azotobacter & Negatif & Batang & $1,5 \mu \mathrm{m}$ \\
Azospirillum & Negatif & Batang & $2,5 \mu \mathrm{m}$ \\
Pseudomonas & Negatif & Batang & $2 \mu \mathrm{m}$ \\
\hline
\end{tabular}

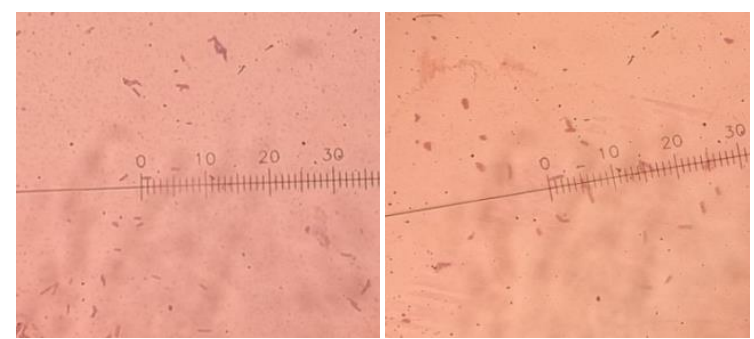

(a) (b)

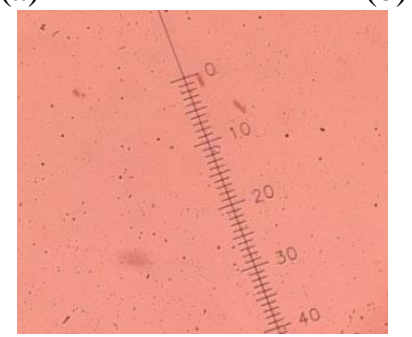

(c)

Gambar 1. Bentuk sel dan gram bakteri anggota genus Azotobacter (1KSA) yaitu berbentuk batang, gram negatif (a); Bakteri Azospirillum (2KSA) berbentuk batang, gram negatif (b); Bakteri Pseudomonas (3KSA) berbentuk batang, gram negatif (c). Gambar diambil dengan perbesaran 1000x.

Tabel 3. Hasil Uji Biokimia dan Identifikasi Isolat Bakteri Penambat Nitrogen

\begin{tabular}{cccc}
\hline \multirow{2}{*}{ Uji } & \multicolumn{3}{c}{ Genus } \\
\cline { 2 - 4 } & Azotobacter & Azospirillum & Pseudomonas \\
\hline Glukosa & + & + & + \\
Orhnitin & - & - & - \\
$\mathrm{H}_{2} \mathrm{~S}$ & - & - & - \\
Gas & + & + & + \\
Indol & - & - & - \\
Usease & + & + & + \\
VP & + & + & + \\
Sitrat & + & + & + \\
Gelatin & + & + & + \\
Sukrosa & + & + & + \\
Laktosa & + & + & + \\
Motilitas & + & + & + \\
NFB & + & + & + \\
\hline
\end{tabular}


Faktor Lingkungan dan Analisis Kimiawi Tanah Hutan Mangrove Sungai Peniti, Kabupaten Mempawah

Kesuburan tanah hutan mangrove Peniti berdasarkan hasil uji kimiawi tanah tertera pada Tabel 4. Hasil pengukuran faktor lingkungan tertera pada Tabel 5.

Tabel 4. Hasil Analisis Kimiawi Tanah Hutan Mangrove Peniti, Kabupaten Mempawah

\begin{tabular}{cccccc}
\hline & \multicolumn{5}{c}{ Kimiawi Tanah } \\
Lokasi & $\mathrm{pH}$ & $\mathrm{C}$ & $\mathrm{N}$ & Rasio & KTK \\
& & $(\%)$ & $(\%)$ & $\mathrm{C} / \mathrm{N}$ & $\left(\mathrm{cmol}^{(+)} \mathrm{kg}^{-1}\right)$ \\
\hline $\mathrm{A}$ & 7 & 6.88 & 0.74 & 9.30 & 27.03 \\
$\mathrm{~B}$ & 6.9 & 6.51 & 0.72 & 9.04 & 25.83 \\
$\mathrm{C}$ & 7 & 3.23 & 0.37 & 8.73 & 12.10 \\
$\mathrm{D}$ & 6.9 & 3.05 & 0.34 & 8.97 & 11.75 \\
\hline
\end{tabular}

Tabel 5. Hasil Pengukuran Faktor Lingkungan Hutan Mangrove Peniti, Kabupaten Mempawah

\begin{tabular}{ccccc}
\hline $\begin{array}{c}\text { Faktor } \\
\text { Lingkungan }\end{array}$ & $\mathrm{A}$ & $\mathrm{B}$ & $\begin{array}{c}\text { Lokasi } \\
\mathrm{C}\end{array}$ & $\mathrm{D}$ \\
\hline $\begin{array}{c}\text { Suhu Udara } \\
\left({ }^{\circ} \mathrm{C}\right)\end{array}$ & 7 & 6.88 & 0.74 & 9.30 \\
$\begin{array}{c}\text { Kelembapan } \\
\text { Udara (\%) }\end{array}$ & 6.9 & 6.51 & 0.72 & 9.04 \\
$\begin{array}{c}\text { Suhu Tanah } \\
\left({ }^{\circ} \mathrm{C}\right)\end{array}$ & 7 & 3.23 & 0.37 & 8.73 \\
$\begin{array}{c}\text { Kelembapan } \\
\text { Tanah }(\%)\end{array}$ & 6.9 & 3.05 & 0.34 & 8.97 \\
$\begin{array}{c}\text { Intensitas } \\
\text { Cahaya } \\
(\text { lux })\end{array}$ & 27.03 & 25.83 & 12.10 & 11.75 \\
\hline
\end{tabular}

\section{PEMBAHASAN}

Isolasi bakteri yang dilakukan pada sampel tanah mangrove di Sungai Peniti pada media NFB bertujuan mengetahui kemampuan bakteri dalam proses penambatan nitrogen bebas.Hasil uji bakteri penambat nitrogen yang dilakukan terhadap tiga isolat terpilih dari hasil proses isolasi, didapat sebanyak tiga isolat positif yang mampu menambat nitrogen pada medium NFB semi solid.Media NFB tidak mengandung unsur nitrogen pada komposisi bahannya sehingga isolat yang dapat ditumbuhkan dalam media tersebut ialah isolat yang mampu menambat nitrogen bebas. Pada sampel tanah yang diinokulasi ke dalam media semisolid NFB menghasilkan 3 isolat terpilih. Pemilihan isolat berdasarkan pada kemampuan dalam penambatan nitrogen bebas. Bakteri yang diduga dapat menambat nitrogen bebas juga memiliki kemampuan untuk mengubah $\mathrm{pH}$ media menjadi lebih basa. Hal ini ditandai dengan perubahan warna media yang semula berwarna kuning kehijauan menjadi berwana kebiruan (Kumar dan Pannerselvam, 2013).

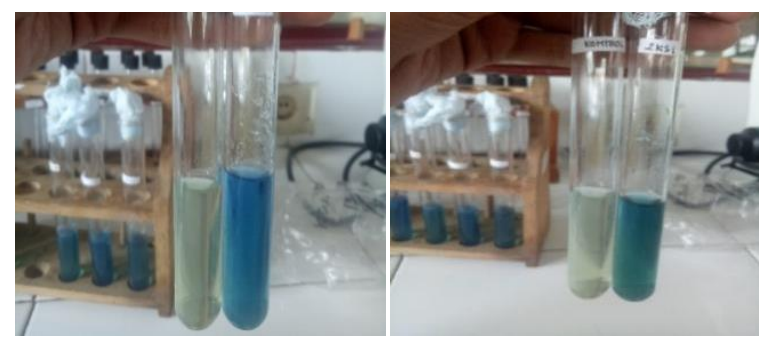

(a) (b)

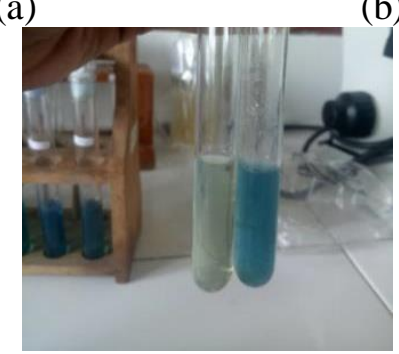

(c)

Gambar 2. Uji penambat nitrogen genus Azotobacter (1KSA) menunjukan perubahan warna biru menandakan uji tersebut positif (a), Uji penambat nitrogen genus Azospirillum (2KSA) menunjukan perubahan warna biru menandakan uji tersebut positif (b), Uji penambat nitrogen genus Pseudomonas (3KSA) menunjukan perubahan warna biru menandakan uji tersebut positif (c).

Ketiga isolat diketahui memiliki potensi sebagai bakteri penambat nitrogen dari hasil uji kemampuannya pada media NFB semisolid dengan penambahan senyawa indikator bromthymol blue(Gambar 2). Menurut Haran dan Ansori (1992), perubahan warna pada media NFB terjadi karena sifat indikator bromthymol blue yang berubah menjadi biru pada $\mathrm{pH}$ yang lebih tinggi, hal tersebut karena adanya aktivitas nitrogenase, didukung dengan Nurosid et al. (2008) yang menyatakan bahwa media NFB semi solid mampu menyediakan nutrisi yang dibutuhkan oleh bakteri penambat nitrogen non simbiosis, perubahan warna biru pada media NFB semi solid menunjukan bahwa terdapat aktivitas nitrogenase yang dilakukan oleh bakteri penambat nitrogen non simbiosis. Hal ini membuktikan bahwa dalam sampel tanah kawasan hutan mangrove Peniti, Kabupaten Mempawah, memiliki potensi sebagai mikroba pemfiksasi nitrogen non simbiosis yang ikut berperan dalam pertumbuhan tumbuhan, sehingga tumbuhan dapat tumbuh dengan baik tanpa melalui pemupukan.

Berdasarkan hasil karakterisasi dan identifikasi yang dilakukan terhadap tiga isolat terpilih dari hasil proses uji penambat nitrogen, didapat sebanyak tiga genera bakteri yaitu isolat bakteri 
anggota genus Azotobacter (1KSA), Azospirillum (2KSA), dan Pseudomonas (3KSA).Hasil dari karakterisasi morfologis dan uji biokimia menunjukkan bahwa bahwa isolat $1 \mathrm{KSA}$ termasuk golongan bakteri gram negatif dan bentuk selnya batang. Karakter morfologis koloni bakteri tersebut yaitu bentuk bulat, tepian tidak rata, elevasi konveks dan berwarna kuning. Karakter fisiologis berdasarkan uji biokomia yaitu bersifat motil, gelatin, urea, voges-proskauer, sitrat memiliki reaksi positif, sedangkan reaksi negatif ditunjukan dengan tidak memproduksi $\mathrm{H}_{2} \mathrm{~S}$, indol, dan orhnitin. Reaksi pada media TSIA yaitu A/A (glukosa, sukrosa dan laktosa difermentasikan). Menurut Holt et al. (1994) dan Cowan et al. (1993), anggota genus Azotobacter memiliki bentuk sel ovoid, batang maupun kokus, berdiamater $1,5-2,0 \mu \mathrm{m}$, terjadi secara tunggal, berpasangan atau gumpalan yang tidak teratur, dan terkadang berantai dengan panjang yang bervariasi. Bakteri gram negatif, bersifat motilit dengan adanya flagella, namun ada juga yang non-motil, hal ini sesuai dengan hasil yang diamati yaitu isolat bakteri anggota genus Azotobacter (1KSA) memiliki sel berbentuk batang dengan ukuran sel 1,5 $\mu \mathrm{m}$, bakteri bersifat gram negatif, dan mempunyai sifat motil, bersifat aerobik namun juga bisa tumbuh pada oksigen yang sedikit, kemoorganotropik, menggunakan gula, alkohol, garam, serta asam organik untuk pertumbuhan, dan mempunyai kemampuan fiksasi nitrogen.

Menurut penelitian Norpansyah dan Rifal (2016), anggota genus Azotobacter memiliki ciri morfologi koloni berwarna kuning bulat, tepian tidak rata, elevasi konveks, hasil pewarnaan gram negatif dengan bentuk sel ovoid, namun pada penelitian Metasari (2012), bentuk makroskopis dari koloni anggota genus Azotobacter berbentuk bulat dengan warna koloni kuning, memiliki tepian tidak rata maupun rata, bentuk elevasi konveks, bentuk sel dari hasil pewarnaan gram berbentuk vibroid maupun ovoid dan gram negatif.

Berdasarkan pengukuran terhadap faktor lingkungan di lokasi pengambilan sampel menunjukan $\mathrm{pH}$ tanah sekitar 6,9-7, hal ini sesuai dengan pernyataan Holt et al. (1994) yaitu anggota genus Azotobacter mampu tumbuh pada $\mathrm{pH}$ berkisar antara 4,8-8,5 dengan $\mathrm{pH}$ optimum untuk pertumbuhan dan fiksasi nitrogen yaitu berkisar 7,07,5. Beberapa spesies memanfaatkan garam nitrat dan ammonium dan asam amino tertentu sebagai sumber nitrogen. Bakteri ini terdapat di tanah maupun di perairan, beberapa spesies bersimbiosis dengan akar tanaman dan dapat ditemukan di hutan mangrove. Hal ini menunjukkan bahwa hutan magrove Peniti mendukung pertumbuhan bakteri anggota genus Azotobacter.
Berdasarkan hasil dari karakterisasi morfologis dan uji biokimia bahwa isolat 2KSA termasuk golongan bakteri gram negatif dan bentuk selnya batang. Memiliki karakter morfologis koloni bentuk bulat, tepian rata, elevasi konveks dan berwarna kuning. Bersifat motil, gelatin, urea, voges-proskauer, sitrat memiliki reaksi positif, sedangkan reaksi negatif ditunjukan dengan tidak memproduksi $\mathrm{H}_{2} \mathrm{~S}$, indol, dan orhnitin. Reaksi pada media TSIA yaitu A/A (glukosa, sukrosa dan laktosa difermentasikan). Menurut Holt et al. (1994) dan Cowan et al. (1993), anggota genus Azospirillum memiliki bentuk sel vibroid atau batang dengan panjang 0,9-1 $\mu \mathrm{m}$. Sel gram negatif ke variabel gram. Sel bersifat motil dengan menggunakan flagella. Isolat bakteri ini mempunyai kemampuan memfiksasi nitrogen, hal ini sesuai dengan hasil yang diperoleh bahwa isolat bakteri anggota genus Azospirillum (2KSA) memiliki sel berbentuk batang dengan ukuran sel 2,5 $\mu \mathrm{m}$, bakteri bersifat gram negatif, dan mempunyai kemampuan motilitas.

Hasil penelitian Norpansyah dan Rifal (2016), menunjukan bahwa anggota genus Azospirillum memiliki ciri makroskopis koloni berwarna kuning bulat dengan elevasi konveks dan tepi rata, hasil perwernaan gram negatif. Menurut Reis et al. (2011), Azospirillum merupakan bakteri aerobik kemoorganotrof non fermentatif, dan memproduksi fitohormon yaitu auksin. Bakteri tersebut menggunakan beberapa sumber karbon terutama gula dan alkohol, selain itu mampu merombak bahan organik didalam tanah seperti kelompok karbohidrat seperti selulosa, amilosa, dan bahan organik lainnya.

Berdasarkan pengukuran terhadap faktor lingkungan menunjukkan lokasi pengambilan sampel memiliki pH tanah sekitar 6,9-7 dan suhu tanah berkisar antara $27-29^{\circ} \mathrm{C}$, hal ini sesuai dengan pernyataan Holt et al. (1994) bahwa anggota genus Azospirillum memiliki suhu pertumbuhan yaitu berkisar $34-37^{\circ} \mathrm{C}$, tumbuh baik pada $\mathrm{pH} 7$ dan menyukai $\mathrm{pH}$ yang bersifat asam, memiliki kemampuan memfermentasi gula, oksidase positif, bersifat kemoorganotropik, autotrof hidrogen fakultatif. Selain itu, bakteri ini dapat tumbuh baik pada garam asam organik, seperti asam malat, asam suksinat, asam laktat, dan asam piruvat, menggunakan karbohidrat sebagai sumber karbon. Dapat ditemukan dan hidup bebas di dalam tanah maupun bersimbiosis dengan akar tanaman sehingga dapat ditemukan di tanah hutan mangrove. Oleh karena itu, bakteri anggota genus Azospirillum juga dapat ditemukan di hutan mangrove Peniti, Kalimantan Barat. 
Hasil penelitian Norpansyah dan Rifal (2016), menunjukan bahwa anggota genus Azospirillum memiliki ciri makroskopis koloni berwarna kuning bulat dengan elevasi konveks dan tepi rata, hasil perwarnaan gram negatif. Menurut Reis et al. (2011), Azospirillum merupakan bakteri aerobik kemoorganotrop non fermentatif, dan memproduksi fitohormon yaitu auksin. Bakteri tersebut menggunakan beberapa sumber karbon terutama gula dan alkohol, selain itu mampu merombak bahan organik didalam tanah seperti kelompok karbohidrat seperti selulosa, amilosa, dan bahan organik lainnya.

Berdasarkan hasil pengukuran faktor lingkungan yang telah dilakukan, anggota genus Azospirillum dapat ditemukan pada daerah mangrove yang memiliki suhu tanah berkisar $27-29^{\circ} \mathrm{C}$ dan $\mathrm{pH}$ berkisar antara 6,9-7, dan memiliki salinitas karena terletak pada daerah pantai, hal ini didukung oleh Widawati (2011), bahwa pada seluruh isolat bakteri anggota genus Azospirillum yang diisolasi dari ekosistem pantai dapat tumbuh dengan baik pada media yang mengandung $\mathrm{NaCl}$, karena bakteri tersebut telah beradaptasi pada habitat yang memiliki salinitas tinggi. Menurut Holt et al. (2002), ada beberapa spesies dari anggota genusAzospirillum yang dapat tumbuh pada salinitas tinggi $(\mathrm{NaCl} 3 \%)$ seperti anggota spesies $A$. brasilense, A. halopraeferens, dan A. irakense, dan ada yang tidak dapat tumbuh pada tingkat salinitas tinggi seperti anggota spesies $A$. amazonese. Namun pada anggota spesies $A$. brasilense menunjukan kemampuan untuk tumbuh pada salinitas $\mathrm{NaCl}$ sampai 4\% (Ravikumar et al., 2002).

Berdasarkan hasil karakterisasi morfologis dan uji biokimia bahwa isolat 3KSA termasuk golongan bakteri gram negatif dan bentuk selnya batang. Karakter morfologis koloni bakteri tersebut yaitu bentuk bulat, tepian tidak rata, elevasi konveks dan berwarna putih transparan. Karakter fisologis berdasarkan uji biokimia yaitu bersifat motil, gelatin, urea, voges-proskauer, sitrat memiliki reaksi positif, sedangkan reaksi negatif ditunjukan dengan tidak memproduksi $\mathrm{H}_{2} \mathrm{~S}$, indol, dan orhnitin. Reaksi pada media TSIA yaitu A/A (glukosa, sukrosa dan laktosa difermentasikan). Menurut Holt et al. (1994), dan Cowan et al. (1993), anggota genus Pseudomonas memiliki bentuk batang lurus atau sedikit melengkung tidak heliks dengan panjang 1,5-5,0 $\mu \mathrm{m}$ dan lebar $0,5-1,0 \mu \mathrm{m}$, sel strain gram negatif, motilitas terjadi oleh satu atau beberapa flagella di polar dan jarang non-motil, hal ini sesuai dengan hasil yaitu bentuk sel berbentuk batang dengan ukuran sel $2 \mu \mathrm{m}$, bakteri bersifat gram negatif, dan mempunyai kemampuan motilitas, bersifat aerobik, dapat juga pertumbuhan terjadi secara anaerobik, mampu menggunakan $\mathrm{H}^{2}$ atau CO sebagai sumber energi, ditemukan secara luas di alam seperti di dalam tanah maupun diperairan sehingga dapat ditemukan di tanah hutan mangrove. Menurut David et al. (2011), anggota genus Pseudomonas bersifat motil dengan flagella, beberapa strain flagella lateral juga ditemukan terutama dalam kultur yang masih baru. Kebanyakan strain genus ini mampu menghidrolisis pati, dapat ditemukan di dalam tanah dan air menggunakan berbagai sumber karbon.

Pada penelitian Isti'anah (2014), hasil identifikasi berdasarkan karakter fisiologis diduga merupakan anggota spesies Pseudomonas luteola, memiliki ciri koloni bentuk bulat, tepian licin dan beraturan, elevasinya cembung, serta hasil perwarnaan gram negatif dengan bentuk sel batang. Bakteri tersebut mempunyai suhu optimum pertumbuhan pada 30$37^{\circ} \mathrm{C}$. Selain itu, Stieglmeier et al. (2009), menyatakan bahwa anggota genus Pseudomonas berhasil diisolasi dalam medium tanpa nitrogen sehingga diketahui bahwa spesies tersebut merupakan bakteri penambat nitrogen bebas.

Berdasarkan hasil pengukuran faktor lingkungan yang telah dilakukan menunjukkan bahwa anggota genus Pseudomonas dapat ditemukan pada daerah Mangrove yang memiliki suhu tanah berkisar 27$29^{\circ} \mathrm{C}$ dan $\mathrm{pH}$ berkisar antara 6,9-7. Menurut Moore et al. (2006), bakteri anggota genus Pseudomonas merupakan bakteri yang dapat tumbuh dan berkembang dengan baik dilingkungan dengan kebutuhan nutrisi sederhana seperti senyawa karbon yang digunakan untuk melakukan metabolisme. Bakteri anggota genus Pseudomonas dapat tumbuh diberbagai habitat seperti lingkungan tanah, air, tanaman maupun jaringan hewan. Pada umumnya anggota genus Pseudomonas mampu tumbuh pada suhu $4-42^{\circ} \mathrm{C}$ dan $\mathrm{pH}$ berkisar antara 4-8. Bakteri anggota genus Pseudomonas merupakan bakteri aerob dan ditemukan di tanah maupun air yang memiliki kondisi $\mathrm{pH}$ aerobik, mesofilik maupun netral. Hal ini menunjukkan bahwa bakteri anggota Pseudomonas juga dapat tumbuh di hutan mangrove Peniti, Kalimantan Barat.

\section{DAFTAR PUSTAKA}

Cowan, ST, Steel, KJ, Barrow, GI, \& Feltham, RKA,1993, Cowan and Steel's Manual for The Identification of Medical Bacteria 3rd Edition, Cambridge University Press, Australia

David, WU \& Ozen, AI, 2011, 'Defining the Pseudomonas Genus: Where Do We Draw the 
Line with Azotobacter?', Journal Microb Ecol, no. 63 , hal. $239-28$

Gunarto, 2004, 'Konservasi Mangrove Sebagai Pendukung Sumber Hayati Perikanan Pantai', Jurnal Litbang Pertanian, vol. 23, no. 1, hal. 1621

Hartono, \& Jumadi, O, 2014, 'Seleksi dan Karakterisasi Bakteri Penambat Nitrogen Non Simbiotik Pengekskresi Amonium Pada Tanah Pertanaman Jagung (Zea mays L.) dan Padi (Oryza sativa L.) Asal Kabupaten Barru, Sulawesi Selatan, Indonesia', Jurusan Biologi FMIPA Universitas Negeri Makassar, Jurnal Sainsmart, vol. 3, no. 2, hal. 143-153

Hasan, S, \& Ansori, N, 1992, Bioteknologi Pertanian Bogor Pusat Antar Universitas Bioteknologi, Institut Pertanian Bogor Press, Bogor

Holt, JG, Krieg, NR, Sneath, PHA, Staley, JT \& Williams, ST, 1994, Bergey's Manual Determinative Bacteriology, Edisi $\mathrm{Ke}$ 9, Lippincott Williams dan Wilki NS, Amerika

Isti'anah, I, 2014, Isolasi dan Seleksi Bakteri Penambat Nitrogen dan Hasil Indole-3-Acetic Asal Sampel Tanah Dari Jambi Indonesia, Skripsi, Jurusan Biologi, Fakultas Matematika dan Ilmu Pengetahuan Alam, Institus Pertanian Bogor, Bogor

James, EK, \& Olivares, FL, 1997, 'Infection and Colonization of Sugar Cane And Other Gramineous Plants By Endophytic Diazotrophs', JournalCrit Rev Plant Sci, no. 17, hal 77-119

Kaburuan, R, Hapsoh, Gusmawartati, 2014, 'Isolasi dan Karakterisasi Bakteri Penambat Nitrogen NonSimbiotik Tanah Gambut Cagar Biosfer Giak SiaK Kecil-Bukit Batu', Jurusan Agroteknologi Fakultas Pertanian Universitas Riau, Jurnal Agroteknologi, vol. 5, no. 1, hal. 35-39

Kumar, S, \& Pannerselvam, A, 2013, 'Studies on Azospirillum isolated from the soils of Thiruvarur Dt.Tamilnadu, India, Journal $A d v$ Appl Sci Res, vol.4, no.2, hal. 86-93

Metasari, K, 2012, 'Eksplorasi Bakteri Penambat Nitrogen Non Simbiosis Dari Tanah Kawasan Hutan Mangrove Wonorejo Surabaya', Program Studi Biologi Fakultas Sains dan Teknologi Universitas Airlangga, Jurnal, Surabaya

Moore, ERB, Tindall, BJ, Santos, Vitor APMD, Pieper, DH, Ramos, LS, Palleroni, NJ, 2006, 'Nonmedical : Pseudomonas', Journal Prokaryotes, Vol. 6, Hal. 646-707

Norpansyah \& Rifal M, 2016, Eksplorasi Mikroba Fiksasi Nitrogen Non Simbiosis Dari Tanah Kawasan Mangrove Di Desa Srimulyo Kecamatan Air Saleh Kabupaten Banyuasin Serta Sumbangsihnya Pada Materi Bakteri Kelas X Di
SMA/MA, Skripsi, UIN Raden Fatah Palembang, Palembang

Nurosid, O, Lestari, \& Puji, 2008, 'Kemampuan Azospirillum sp. JG3 dalam Menghasilkan Lipase pada Medium Campuran Dedak dan Oggok dengan Waktu Inkubasi Berbeda', Jurnal, Universitas Soedirman, Purwokerto

Ravikumar, S, Ramanathan, G, Suba, N \& Jayaseeli, L 2002, Quantifcation of Halophilic Azospirillum From Mangroves, Indian J. Mar. Sci., vol. 31, no. 2

Reis, VM, Teixeira, KRDS, \& Pedraza, RO, 2011, 'What Is Expected from the Genus Azospirillum as a Plant Growth-Promoting Bacteria? In Bacteria in Agrobiology: Plant Growth Responses', D.K. Maheshwari (ed.), Springer-Verlag, Heidelberg, Berlin

Santono, N, 2000, Pola Pengawasan Ekosistem Mangrove, Lokakarya Nasional Pengembangan Sistem Pengawasan Ekosistem Laut, Jakarta

Setyawan, AD, \& Winarno, K, 'Pemanfaatan Langsung Ekosistem Mangrove di Jawa Tengah dan Penggunaan Lahan di Sekitarnya; Kerusakan dan Upaya Restorasinya', Jurusan Biologi FMIPA Universitas Sebelas Maret (UNS), Surakarta, Biodiversitas, vol.7, no. 3, hal. 282291

Stieglmeier M, Wirth R, Kminek G, Moils-Eichinger C, 2009, 'Cultivation of Anaerobic and Facultatively Anaerobic Bacteria from Spacecraft-Assosiated Clean Rooms', Appl Environ Microbial, vol. 75, no. 11, hal. 34843491

Susilowati, D.N, Saraswati R., Hastuti, R.D., dan Yuniarti, E, 2007, 'Peningkatan Serapan N Pada Kedelai Yang Diinokulasi Bakteri Diazotrof Endofit di Medium Vermiculit', Jurnal Tanah Iklim, Bogor, no. 24, hal. 41-46

Waluyo, Lud, 2008, Teknik Dan Metode Dasar Dalam Mikrobiologi, Universitas Muhammadiyah Malang Press, Malang

Widawati, S, 2011, 'The Role of Phosphate Solubilizing Bacteria and Freeliving Nitrogen Fixing Bacteria on The Growth and Adaptation of Gmelina arborea Roxb. Grown on Degraded Land', Journal Environ Engineering, vol. 7, no. 1, hal. 89-95 